\title{
Mobile Phone Use by Zimbabwean Smallholder Farmers: A Baseline Study
}

\section{Samuel Musungwini}

Lecturer, Department of Information Systems, Faculty of Commerce, Midlands State University, Gweru, Zimbabwe; and PhD Candidate, University of South Africa (UNISA), Pretoria

\begin{abstract}
This article provides findings from a baseline study on mobile phone use by smallholder farmers in Zimbabwe. The study investigated use of mobile phones by 58 farming households in a village in Zimbabwe's Midlands Province. Via a survey questionnaire and a focus group discussion, the study found that $100 \%$ of the surveyed households identified "asymmetry of information" as a challenge they face in their agricultural activities, and $90 \%$ cited "absence of market information" as a challenge. Yet at the same time, the study found low levels of household mobile phone usage, with only $50 \%$ of households were found to be using mobile telephony in support of a farming activity. The article concludes with a recommendation for how to close this apparent gap between the smallholder farmers' felt need for increased agricultural information and, at the same time, their lack of use of mobile telephony to access such information.
\end{abstract}

\section{Keywords}

mobile technologies, information and communication technology (ICT), smallholder agriculture, smallholder farmers, spatial arbitrage, time arbitrage

DOI: $\underline{\text { https://doi.org/10.23962/10539/26171 }}$

\section{Recommended citation}

Musungwini, S. (2018). Mobile phone use by Zimbabwean smallholder farmers: A baseline study. The African Journal of Information and Communication (AJIC), 22, 29-52. https://doi.org/10.23962/10539/26171

\section{Acknowledgements}

The author thanks all those who participated in this research; for without them, this work would not have been a success. Special thanks go to two farmers, who will remain anonymous, for their immense contribution in this work through assisting the researchers in administering the questionnaires.

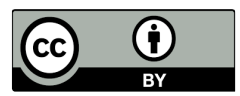

This article is licensed under a Creative Commons Attribution 4.0 International (CC BY 4.0) licence: http://creativecommons.org/licenses/by/4.0 


\section{Introduction}

Smallholder agriculture has a direct influence on the rural livelihoods of rural Zimbabweans. Viability, productivity and sustainability of smallholder farming are critical for attainment of UN Sustainable Development Goals in Zimbabwe, particularly Goals 1, 2 and 8 (UN, n.d.). Studies have found that smallholder farmers able to secure increased access to information, appropriate technology, suitable markets, suitable credit, and better prices, and insurance are likely to be more productive and more sustainably develop (Bagazonzya, Safdar, \& Sen, 2012; Jayne, Mather, \& Mghenyi, 2006; Mago, 2012; Musungwini, 2016; Palmer, 2012; Pienaar \& Traub, 2015; Tadesse \& Bahiigwa, 2015; World Bank, 2011). And smallholder farmers with limited access to the above-listed elements, and often also faced with unsupportive government policies, droughts, and demographic pressures, are underproductive (Mittal, 2012; Mutami, 2015; Von Loeper, Musango, Brent, \& Drimie, 2016).

Meanwhile, in Sub-Saharan Africa, as elsewhere in the developing world and in the developed world, the mobile phone and mobile information and communication technologies (ICTs) are transforming the manner in which people interrelate, unlocking exhilarating and unexplored opportunities in support of trade (Musungwini et al., 2014), and transforming all facets of life (Duncombe \& Boateng, 2009; Ogunleye, 2010; Walsh \& Power, 2011). Among the myriad sectors where mobile ICTs are having a profound impact is in developing-world smallholder agricultural settings.

Most smallholder farming systems are much less productive and profitable than they could be (Brugger, 2011; FAO, 2011; Nguthi, 2007). ICTs, and in particular mobile ICTs, are often seen as game-changers in smallholder agriculture. In one study in Tanzania, mobile phones were found to be responsible for increasing farmers' profits by $15 \%$ (Furuholt \& Matotay, 2011). De Silva and Ratnadiwakara (2008), researching the impact of ICTs on rural agriculture in Sri Lanka, found that a key challenge smallholder farmers faced, and which ICTs could potentially address, was information asymmetry, or information lop-sidedness, whereby rural smallholders typically possess less of the important market and other information than the buyers and other more powerful actors they interact with in pursuit of their livelihoods. And Qiang, Kuek and Dymond (2011) have found that among the key barriers that developing-world smallholder farmers face are the information and skills gaps that constrain adoption of available technologies and technology-enabled management practices - or reduce the technical efficiency of these practices when adopted (Qiang et al., 2011).

The empirical data on mobile phone use by smallholder farmers in Sub-Saharan African settings is still very limited. The research on which this article is based sought to begin to address that gap in the Zimbabwean context, specifically in respect of the 
smallholder farmers of Havana Extension village in the Tokwe resettlement area, Shurugwi District, Midlands Province. The specific objectives of the research were to establish: the main agricultural practices of the smallholder farmers; the challenges faced by the farmers in their agricultural activities; the farmers' sources of agricultural information; the farmers' level of mobile phone ownership; the farmers' main uses of mobile phones; and the extent of farmers' use of mobile phones for farming activities.

\section{Background}

Sub-Saharan Africa is home to many countries that have the bulk of their population living below the poverty line and residing in rural areas. The livelihoods of these people are often wholly dependent on farming. According to a 2012 estimate by ZIMSTAT (2012), more than $67 \%$ of the population of Zimbabwe, then estimated at 14.7 million people, was residing in rural areas, where they depended on farming as a source of livelihood. Today, Zimbabwe's population is estimated at over 16 million (Trading Economics, n.d.), and it can be presumed that the majority still lives in rural areas given, among other things, the closure of many urban-based companies in the period 2012 and 2017 (as reported by Mugova (2017), Nkomo (2016), Samukange \& Mutomba (2014), and Vusani (2015)).

After the country's independence in 1980, the Zimbabwean Government established agriculture marketing boards to administer and manage harvested crops. For example, grain farmers could acquire inputs from the Grain Marketing Board (GMB), and sell their produce to GMB. For cotton, there was the Cotton Marketing Board (CMB) doing the same. However, the CMB was later privatised and became Cotton Company of Zimbabwe (Cottco). The crumbling of the Zimbabwean economy in the 2000s culminated in the collapse of the agro-processing industry and in the agricultural value chain. The GMB no longer functions well, and there have been cases where it has failed to pay farmers for more than two years for grain collected. Recent years have witnessed an increasing presence by middlemen in the agriculture value chain, providing alternative markets for farmers' produce. However, the use of middlemen brings problems of its own. For example, there have been cases where middlemen bought farmers' produce and paid with fake USD notes.

Midlands Province is Zimbabwe's central province, and Shurugwi District is one of the Midlands Province's most vibrant districts in terms of agriculture, second only to Gokwe District. Statistics from the GMB depot at Tongogara growth point, in Shurugwi District, indicate that the bulk of Shurugwi District's maize deliveries since 1985 come from the Tokwe resettlement area. And within Tokwe, according to agricultural extension (Agritex) officers from the area, Havana Extension is the dominant village in terms of both the number of farmers holding Master Farmer certificates (as awarded through the Agritex system), and farmers' performance in agricultural competitions in the area (Havana farmers usually sweep the prizes). It was for these reasons that I undertook the research in Havana Extension. 


\section{Literature review}

This literature review focuses on contextualising smallholder agriculture in SubSaharan Africa; mobile phone adoption in Sub-Saharan Africa; and mobile phone use in support of smallholder agriculture in Sub-Saharan Africa.

\section{Smallholder agriculture in Sub-Saharan Africa}

A number of articles have looked at the challenges faced by smallholder farmers in Sub-Saharan Africa (Gabagambi et al., 2013; Kavoi et al., 2014; Murray et al., 2016; Musungwini, 2016; Pienaar \& Traub, 2015; Von Loeper et al., 2016). For example, in the Malawian smallholder-farmer context, Murray, Gebremedhin, Brychkova and Spillane (2016) identify the following challenges:

- small size of land and asset holdings;

- low food crop productivity;

- limited choice in respect of inputs and crop types;

- limited market information;

- limited land-use education;

- shifts in urban food consumption in favour of crops not produced by smallholder farmers;

- national government shortcomings, e.g., limited national public expenditure on the agriculture sector; and

- global governance dynamics, including shifts in global agricultural trade policies and declining donor assistance for smallholder farmers.

Similar findings are provided by Masaba (2013), based on research on palm oil smallholder farmers in Uganda, with the following identified as the major challenges:

- limited markets, market access and related marketing infrastructure;

- high cost of, and limited access to, high-quality farm inputs and production technology;

- lack of access to agricultural credit facilities;

- inadequate agricultural extension services;

- decline in the agriculture sector growth;

- lack of ownership and control of land by women; and

- lack of gender analysis to inform policy formulation, planning and budgeting.

Other literature looks more specifically at issues of dryland farming (the type of farming practised in Zimbabwe), and the need for rainwater-harvesting and development of water resources. Cooper, Dimes, Rao, Shapiro, Shiferaw and Twomlow (2008) focus on the need for climate change adaptation mechanisms for smallholder farmers in Sub-Saharan Africa. Adjognon, Liverpool-Tasie and Reardon (2017) argue that the availability of technology, inputs, and market information, while important, are of limited value if smallholder farmers do not also get access to tailored credit facilities. 


\section{Mobile phone adoption in Sub-Saharan Africa}

Across the developing world, mobile phones have pervasively penetrated every facet of life, making tremendous impact on the lives of people (Ilahiane \& Sherry, 2009; Waverman et al., 2005; World Bank, 2012), including reducing the costs of communicating (Baumuller, 2015; Wulystan \& Andrew, 2013; Zanello, 2011).

Developing-world public-sector, private-sector, and civil society actors alike are now able to send and receive information quickly and cheaply on important economic, political, social, and cultural matters (Annan, 2013; OECD \& ITU, 2011; Kushchu, 2004; Page et al., 2013; Potnis, 2014). Accordingly, African policymakers and researchers are now focused on the dynamism and potential provided by the wide variety of mobile digital applications and services. A number of articles have looked at the adoption, use, prevalence, and impact, of mobile telephony in Sub-Saharan Africa. Aker and Mbiti (2010) look at how exponential growth of mobile telephony in Sub-Saharan Africa has opened new possibilities to the continent. In most of Sub-Saharan Africa, the mobile phone is the only technology accessible to many inhabitants and therefore, across social strata, urban and rural divides, and rich and poor divides, it is facilitating connections between people; access to information; access to markets; and access to services (Aker \& Mbiti, 2010; Jagun et al., 2008; Mekuria, 2007; Rashid \& Elder, 2009; Wamuyu, 2014).

\section{Mobile phone use in support of smallholder agriculture in Sub-Saharan Africa}

The UN 2030 Agenda for Sustainable Development, in which 17 Sustainable Development Goals (SDGs) are identified to be pursued in the quest for a better world for all, gives much prominence to agriculture (UN, n.d.). The development of agriculture is crucial because it has a direct impact on the SDGs 1,2,3 and 8, while indirectly impacting 10 of the other SDGs. The mobile phone has been identified as a key driver for achievement of SDGs (Heeks, 2014a; 2014b). Qureshi and Najjar (2017) found that in developing-world small island states, an extra 10 phones per 100 people can boost GDP growth by $0.8 \%$.

A number of articles have been published which show that the reduction in communication costs and instant delivery of messages associated with mobile telephony have brought with them tangible economic benefits which have greatly improved smallholder agricultural activities in developing countries, including Sub-Saharan African countries (Bonthu, 2014; Duncombe, 2012; Ndiwalana et al., 2008; Ogunleye, 2010; Olsen, 2008; Zanello, 2011). ICTs in general, and mobile technologies in particular, are often touted as the key catalyst to levelling the playing field in smallholder agriculture in developing countries. Developing-world, including African, farmers can obtain real-time market pricing information via mobile telephony, saving time and travel and making them better-informed about where and what price to sell their products, thereby raising their incomes and improving the sustainability of their livelihoods (Beuermann et al., 2012; Furuholt \& Matotay, 
2011; Islam \& Grönlund, 2011; Katengeza et al., 2011; Shaffril et al., 2015; Marshall, 2018; Walsh \& Power, 2011) .

Integral to the aforementioned challenge of information asymmetry, as a vulnerability for rural African farmers, is their scarcity of access to key information on a range of key matters, during farming, transportation, and marketing of their crops (Furuholt \& Matotay, 2011). A study conducted in Niger from 2001 to 2006 found that the introduction of mobile phones reduced grain price dispersion by $6.4 \%$, and reduced price variation by $12 \%$, over the course of one year (Aker \& Mbiti, 2010). In a baseline survey conducted in Tanzania in July 2013, it was established that rural farmers were making wide use of Tigo Kilimo, an agricultural information service developed and deployed by mobile network operator (MNO) Tigo (Pshenichnaya \& Palmer, 2013).

Generally, smallholder farmers value mobile telephony as a fast and a convenient way to communicate with various stakeholders in the agriculture value chain and to get prompt answers in respect of problems they face (Freeman, 2017; Ogbeide \& Ele, 2015). The mobile phone engenders opportunities for the farmers especially in respect of getting marketing and weather information (Churi et al., 2012; Masuka et al., 2016; Ogbeide \& Ele, 2015; Tadesse \& Bahiigwa, 2015). Through mobile telephony, smallholder farmers can directly keep in touch with many clients in various marketplaces, and offer their produce at competitive prices (Zyl, Alexander, Graaf, \& Mukherjee, 2014; Chhachhar, Chen, \& Jin, 2016; Furuholt \& Matotay, 2011; Mansingh \& Erena, 2016). Use of a mobile phone also enables smallholder farmers to be aware of real-time weather forecasts and current information on agricultural inputs such as fertilizers and pesticides (Baumüller, 2015; Mansingh \& Erena, 2016; Wulystan \& Andrew, 2013).

This mobile handset is carving an indelible mark on the socio-economic processes of rural communities in Sub-Saharan Africa, offering new directions and approaches for rural farmers (Bonthu, 2014; Chhachhar et al., 2016; Etwire et al., 2017; Mittal, 2016). Studies indicate that mobile phone technologies are producing energy and time savings for farmers, and ultimately improving their incomes (Baumüller, 2015; Mansingh \& Erena, 2016; Masuka et al., 2016).

In the available literature, the factors found to have a bearing on adoption and effective utilisation of mobile phones in smallholder agriculture can be classified into three categories, as outlined in Table 1. 
Table 1: Factors affecting adoption and use of mobile phones in smallholder agriculture

\begin{tabular}{|c|c|c|}
\hline & Factors & Sources in the literature \\
\hline $\begin{array}{l}\text { Factors } \\
\text { produced } \\
\text { by mobile } \\
\text { phone } \\
\text { capabilities }\end{array}$ & $\begin{array}{l}\text { Mobile phone: } \\
\text { - } \quad \text { can be a tool for education } \\
\text { - } \quad \text { and information costs } \\
\text { can reduce information } \\
\text { asymmetry } \\
\text { capable of providing } \\
\text { information for weather, } \\
\text { input prices, market price for } \\
\text { products, diseases and other } \\
\text { disasters in real-time } \\
\text { capable of facilitating } \\
\text { knowledge-sharing among } \\
\text { farmers } \\
\text { capable of facilitating money } \\
\text { transfer, banking, and } \\
\text { transaction services between } \\
\text { buyers and sellers }\end{array}$ & $\begin{array}{ll}\text { - } & \text { Duncombe (2012) } \\
\text { - } & \text { Foster and Heeks (2013 } \\
\text { - } & \text { Masuka, Matenda, Chipomho, } \\
& \text { Mapope, Mupeti, Tatsvarei, } \\
& \text { and Ngezimana (2016) } \\
\text { - } & \text { Mittal and Mehar (2012 } \\
\text { - } & \text { Musungwini (2016 } \\
\text { - } & \text { Musungwini and Van Zyl } \\
\text { - } & \text { Musungwini, Zhou Tinashe, } \\
\text { - } & \text { Whou, and Ruvinga (2014 } \\
& \text { Wyche and Steinfield (2016) }\end{array}$ \\
\hline $\begin{array}{l}\text { Factors } \\
\text { influencing } \\
\text { mobile } \\
\text { phone use }\end{array}$ & $\begin{array}{ll}\text { - } & \text { mobile phone ownership } \\
\text { - } & \text { education level } \\
\text { - } & \text { gender } \\
\text { - } & \text { age } \\
\text { - } & \text { availability of infrastructure } \\
& \text { accessibility of mobile phone } \\
\text { - } & \text { services } \\
& \text { level of digital knowledge }\end{array}$ & $\begin{array}{ll}\text { - } & \text { Asif, Uddin, Dev, and Miah } \\
& (2017) \\
\text { - } & \text { Hamad, Eltahir, Ali, Hamdan, } \\
\text { - } & \text { Mand Elsafi (2018 } \\
\text { - } & \text { Shaffril, Omar, D’Silva, and } \\
& \text { Bolong (2015) } \\
\text { - } & \text { Morawczynski (2010 } \\
\text { - } & \text { Mutisya (2016) }\end{array}$ \\
\hline $\begin{array}{l}\text { Factors } \\
\text { inhibiting } \\
\text { optimal } \\
\text { mobile } \\
\text { phone use }\end{array}$ & $\begin{array}{ll}\text { - } & \text { lack of necessary knowledge } \\
& \text { and information to use mobile } \\
\text { - } & \text { phones } \\
\text { - } & \text { olliteracy age } \\
\text { - } & \text { lack of infrastructure } \\
\text { - } & \text { gender dynamics } \\
\text { - } & \text { socioeconomic status } \\
\text { - } & \text { high cost of mobile phones } \\
& \text { and mobile services }\end{array}$ & $\begin{array}{ll}\text { - } & \text { Arreymbi, Agbor, and Adnan } \\
& \text { (2008) } \\
\text { - } & \text { Baumüller (2015) } \\
\text { - } & \text { Etwire, Buah, Ouédraogo, } \\
\text { Zougmoré, Partey, Martey, } \\
\text { Dayamba, and Bayala (2017) } \\
\text { - } \quad \text { Islam and Grönlund (2011 } \\
\text { - } \quad \text { Khayyat and Heshmati (2013) } \\
\text { - } \quad \text { Kiilu (2013) } \\
\text { - } \quad \text { Leon, Schneider, and Daviaud } \\
\text { - } \quad \text { Martin and Abbott (2011 } \\
\text { - } \quad \text { World Bank (2012) } \\
\text { - } \quad \text { Wyche and Steinfield (2016) }\end{array}$ \\
\hline
\end{tabular}


With its 103\% mobile penetration rate and 91\% literacy rate (Musungwini et al., 2014), Zimbabwe would appear to be well-placed to see its rural smallholder farmers harness mobile technologies to address some of their challenges.

\section{Research design}

The research data collection instruments used were a survey questionnaire and a focus group discussion. The questions in the survey questionnaire (see Appendix) were multiple-choice with closed-ended responses. I was assisted in the process of administering the questionnaires by two smallholder farmers in the study area. For the focus group discussion, I was the facilitator, and the discussion was recorded on a mobile phone.

Both the survey questionnaire and the focus group sought to probe the following:

- the main agricultural practices of the smallholder farmers;

- the challenges they faced in their agricultural activities;

- their sources of agricultural information;

- their level of mobile phone ownership;

- their main uses of mobile phones;

- and their extent of use of mobile phones for farming activities.

The questionnaire was completed by 58 smallholder farmer households in Havana Extension village. Purposive sampling was used to select Havana out of the other 13 villages in Tokwe resettlement area. As mentioned above, Havana has a history of being generally the most productive village, in terms of agriculture, in the Tokwe resettlement area. There are 60 households in Havana Extension village, and initially it was planned that the questionnaire would be administered to all the households. However, at the time of conducting the research, occupants of two households were not available, and thus 58 households were surveyed. The questionnaires were selfadministered, but with participants answering in the presence of a member of the research team and thus able to seek clarification where necessary.

The focus group participants were: an agricultural extension (Agritex) officer; a veterinary officer who serves farmers in the Tokwe resettlement area; and five smallholder farmers in Tokwe. The farmers were chosen based on their being holders of Master Farmer certificates and via a snowball sampling technique, i.e., after the Agritex officer, veterinary officer, and one farmer had been identified, these three people were asked to help identify the other four farmers. The focus group discussion was conducted primarily in the Shona language, as all participants were found to be more comfortable expressing themselves in Shona than in English. Some of the participation was in a mixture of Shona and English. While there were guiding questions to the focus group discussion (linked to the survey questionnaire questions as provided in the Appendix), some degree of unfocused discussion was included. 


\section{Methodological limitations}

Zimbabwe has smallholder farmers in many different areas, including resettlement areas, small-scale farms, and tribal trust lands commonly called "reserves". Havana Extension village in the Tokwe resettlement area is but one village, and therefore, the experiences of Havana Extension farmers cannot be said to be representative of all Zimbabwean smallholder farmers.

Additionally, while focus group discussions are a vital tool for qualitative research data collection, they also have inherent weaknesses that can affect the outcome of research. Among focus group participants, some may dominate the discussion, and this affects the outcome of the research. Moreover, according to Calder (1977) and Eliot \& Associates (2005), focus groups cannot necessarily be expected to produce reliable data on sensitive topics that appeal to feelings and emotions, with poverty being one such issue. Finally, it must be acknowledged that, in some cases, focus group participants have been found to say things that are contrary to actual observable reality.

\section{Findings}

\section{Respondents'farming activities}

The focus group participants provided valuable contextual information about the farming activities being carried out by smallholder farmers in the area under study:

Farming is a practice which is usually practised by people from all walks of life. When everything else has failed, you find yourself going to the rural areas, and to survive you have to practice farming. Farmers in this area come from diverse backgrounds, but most have a general farming background. (focus group participant)

Farming involves land preparation, which is done [...] usually during harvesting around April-August. We usually plant crops around October and November and [...] late December due to change in weather patterns. It is critical to prepare and plant your crops on time in order to get a good yield. (focus group participant)

The focus group participants indicated that the farmers in the area mainly produced cereals, with maize the main product - as it is the staple food for the majority of the Zimbabwean populace. This finding was echoed in the survey results, with all 58 surveyed households indicating that they produce maize more than any other crop (often in combination with other crops such as groundnuts (peanuts), rapoko (millet), sunflowers, and castor beans).

Twenty-seven of the households indicated that they produced cotton up until 2012 but then stopped. (Cash crops such as cotton can be problematic for smallholder 
farmers because they are not for household consumption. As a consequence, marketing options for cash crops can become unreliable.) The farmers in the study said they ceased producing cotton because they had, as one research participant put it, been "robbed" by Cottco, the aforementioned company set up by government to oversee production and buying of all cotton in Zimbabwe. The farmers expressed deep displeasure at the way Cottco had treated them.

The farmers said they had entered into contract-farming relationships with Cottco, in which each farmer was given inputs for cotton production. Cottco had promised the farmers that upon harvesting, they would be able sell their cotton produce to Cottco at USD1/kg. But after harvesting, the farmers were notified that the price was now USD0.24/kg. The farmers refused to sell for some time, hoping for an improvement in the price. But the price did not change, and they eventually had to sell the cotton to Cottco at the USD $0.24 / \mathrm{kg}$ price. The farmers then ended up owing Cottco money, after the company subtracted the value of inputs (seeds, fertiliser and chemicals) it had advanced to each farmer at the beginning of the farming season. As a result of this experience, all the farmers who participated in this research vowed that they will never produce cotton again. Some of the farmers have started to produce other cash crops, e.g., sunflowers and castor beans.

Thirty-nine of the surveyed households were found to also practise livestock-keeping, for draught power and for selling of animals to augment their incomes, and seven households were practising poultry farming. Twenty-one of the households were practising market gardening, i.e., producing vegetables and tomatoes to sell within the community. Figure 1 shows the survey findings on farming activities.

\section{Figure 1: Respondents' farming activities $(n=58)$}

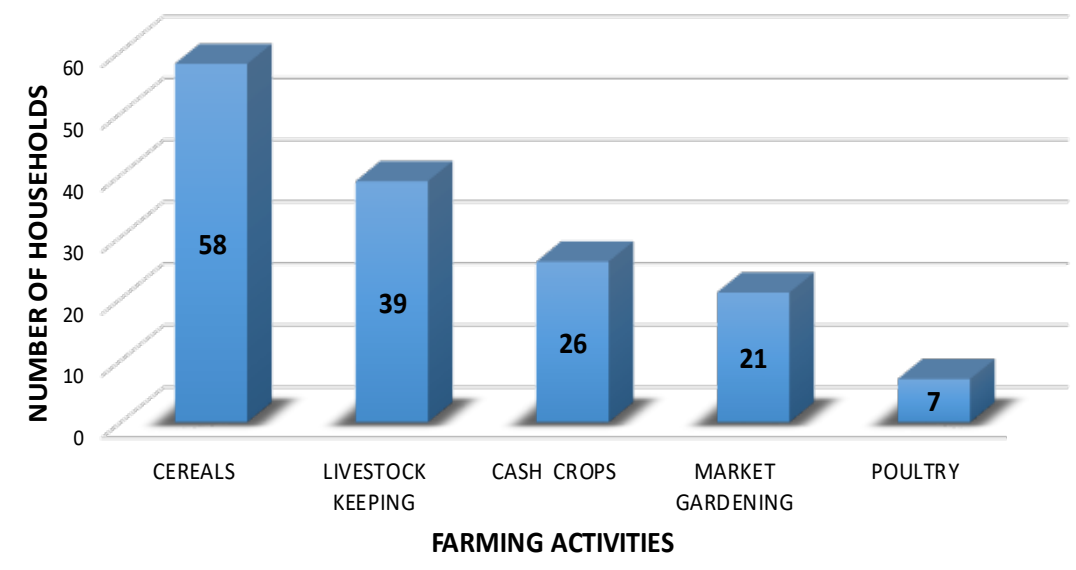




\section{Respondents'challenges faced in agricultural activities}

The survey participants generally agreed that there are inherent problems with smallholder farming in their area. In general, it was found that they see themselves as suffering from an inherent vicious cycle of poverty, i.e., poverty causing poverty.

As seen in Figure 2, the two most-cited challenges in respect of agricultural activities were asymmetry of information and absence of market information, cited by 58 (100\%) and $52(90 \%)$ of surveyed households respectively. This tallies with findings by Aker et al. (2016), Jagun et al. (2008), Kadigi et al. (2013), and Mittal (2016), who have found that such information asymmetry and information absence are major impediments to the development of smallholder agriculture.

Figure 2: Respondents' challenges faced in agricultural activities $(n=58)$

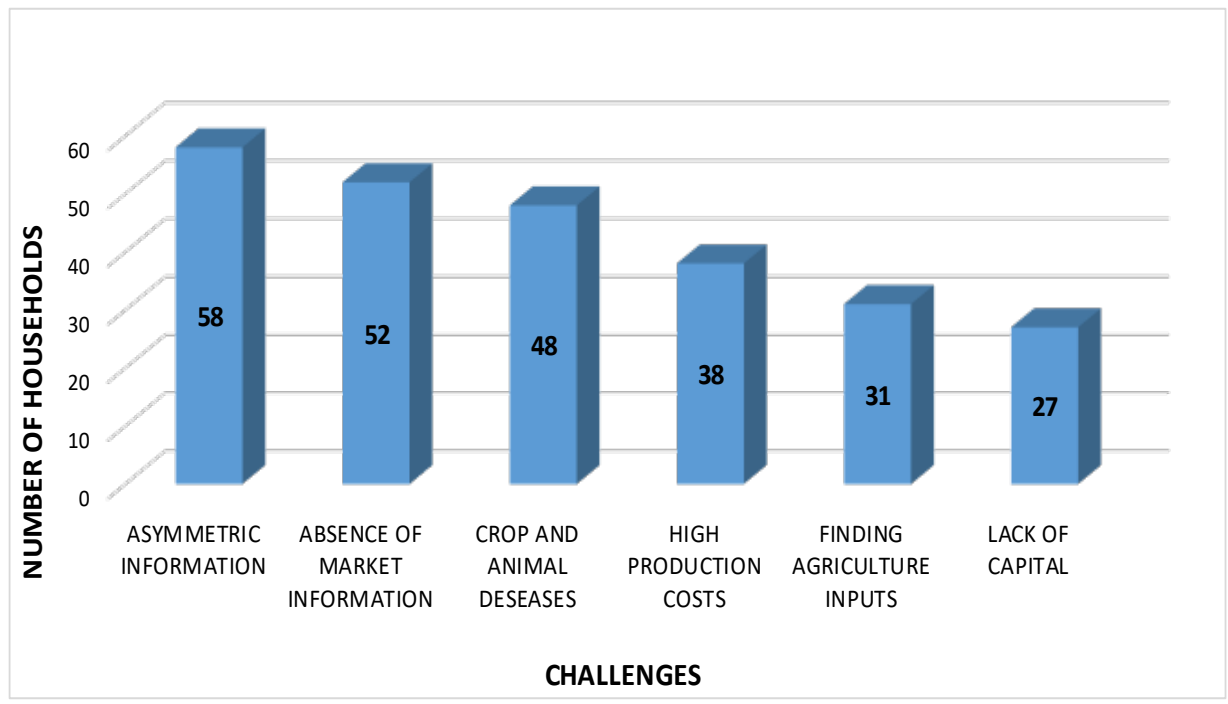

Asymmetry of information, absence of market information

The respondents stated that, in some cases, perishable products go bad due to unavailability of markets, and that when the farmers produce good yields, they seldom benefit as fully as they could. Key causes cited for these difficulties were spatial arbitrage (different market prices for the same commodity in different market places at the same time) and time arbitrage (different prices for the same product at different time intervals). 
According to one focus group participant,

[...] the major challenge is [that] the market price after harvesting is usually very bad, [so] that a farmer may not be able to recover money for input costs. Sometimes when preparing for the crop season, we get very remarkable prices being announced, but soon after harvesting we are told of very low prices. Sometimes as farmers we are compelled to sell our produce to private buyers [middlemen], who come with their cars and buy. And they go on to sell to such perennially dry places as Chirumanzu and Chivi Districts. (focus group participant)

What this focus group participant describes is an illustration of spatial arbitrage: The middlemen, after buying the grain from the farmers, then go and sell the grain at premium prices in drought-stricken areas such as Chivi and Chirumanzu.

In respect of use of time arbitrage, it was said that middlemen and some of the moreestablished smallholder farmers in Shurugwi District are the chief culprits. The more-established smallholder farmers were said to practise hoarding, i.e., they will not sell when they feel the price is not right, and keep their grain until the price goes up. They also buy grain from less-established smallholder farmers at very low prices - and sometimes even sell it back to these very same farmers at high prices when the farmers are desperate for money (to, for instance, buy food to feed their households, or pay school fees).

Respondents spoke of the myriad forms of persuasion middlemen use to entice farmers to part with their yields. For instance, when winter is commencing, the middlemen come with items such as jackets, vaseline, blankets, and sugar. Farmers' circumstances induce them to buy these products from the middlemen, with payment in the form of grain. According to the focus group discussion, in most cases the middlemen have much more pricing information and other important market information than the farmers, allowing the middlemen to be highly exploitative. The farmers said that by the time they get the information they need, it is typically stale and no longer useful.

\section{Respondents'sources of agricultural information}

As shown in Figure 3, all 58 surveyed households said they get agriculturalinformation from an Agritex officer. The next most-used source of agricultural information was found to be radio (47 households), followed by television (27). Twenty-three households said they get farming information through word-of-mouth. Significantly for the purposes of this research, only 12 (21\%) of the households indicated that they receive agricultural information via their mobile phones. 
Figure 3: Respondents' sources of agricultural information $(\mathbf{n}=58)$

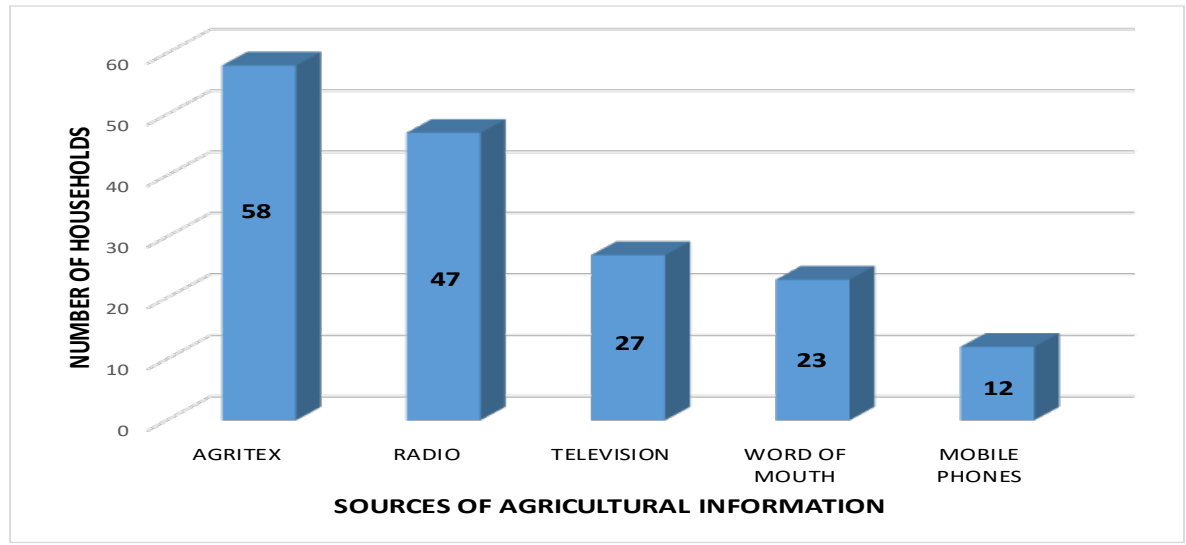

\section{Respondents'uses of mobile phones}

It was found that all 58 households had a mobile phone of some sort, and 37 had more than one (with some households owning up to five mobile phones). Thirty-two of the households had at least one smart phone. Figure 4 shows the uses of mobile phones by the 58 households. All 58 households said, as Figure 5 shows, they use the phones for voice-calling, SMS-messaging and mobile money transfer. The farmers indicated that, through these three uses, the mobile phone has transformed their day-to-day lives.

\section{Figure 4: Respondents' uses of mobile phones $(n=58)$}

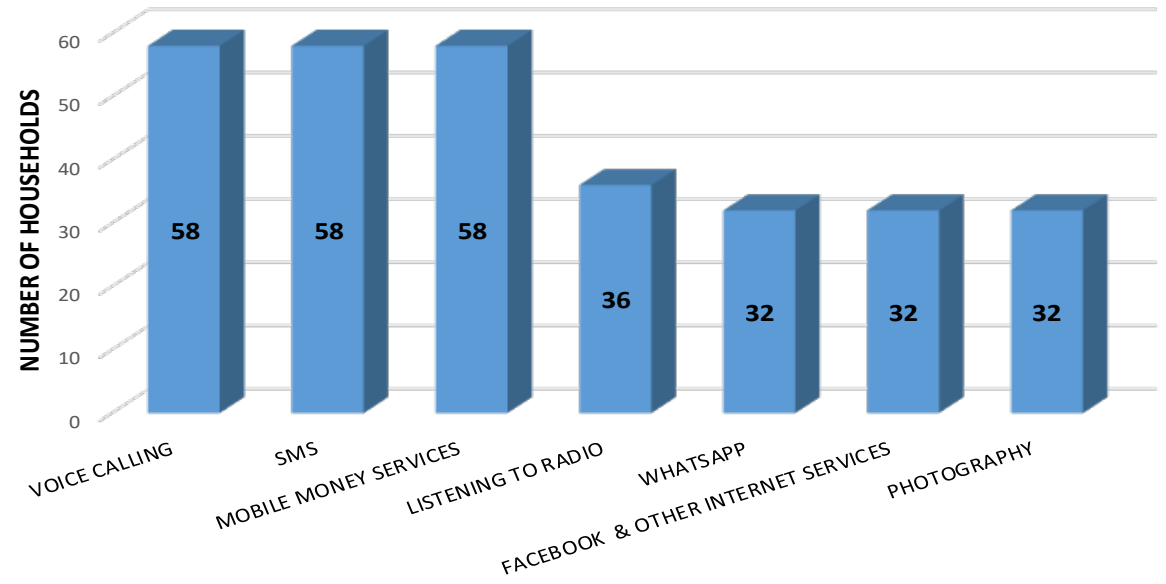

MOBILE PHONE USES 
One focus group participant had this to say, in Shona, concerning mobile phones:

Kune munhu asina cellphone mazuva ano? Ndikasiya cellphone yangu ndinoita sendisina kupfeka. Cellphone yangu yakakosha kudarika doro zvokuti ndikawana mari chekutanga kutenga "juice card" ndozofunga zvedoro.

In English, this translates as:

Is there anyone without a mobile phone these days? When I mistakenly leave my mobile phone I feel like I am naked. My mobile phone is more important than beer and if I get any money the first thing that comes to my mind is to buy a "juice card" [airtime] and then think of beer later. (focus group participant)

Another focus group participant, who had children living in South Africa, stated that:

With my phone, I will never be stranded. Once I SMS my children that I need some money, I receive it within minutes, and I go to the nearest shop and cash out my money. (focus group participant)

The 32 households that had smart phones were found, unsurprisingly, to be the ones who take photos, and use WhatsApp, Facebook and other internet services, with their phones (activities that are not possible on non-smart feature phones).

\section{Respondents'uses of mobile phones in support of farming activities}

Earlier we saw, in Figure 3, that only 12 (21\%) of the households stated that they use mobile phones as a source of agricultural information. However, later in the survey and as shown in Table 2 below, when respondents were given a list of nine farming activities (several of which were agriculture information-gathering activities, such as "enquire for inputs") and asked which ones they use their mobile phones for, it was found that somewhere between 14 and 29 households-i.e., between $24 \%$ and $50 \%$ - were engaging in each of the nine farming activities via their mobile phones. Thus, the number of households using mobile phones for agricultural information (as defined with more nuance in this latter part of the survey) would seem to be higher than the figure of 12 households (21\%) from earlier in the survey suggests.

Nevertheless, even the higher percentages of mobile-phone engagement with agricultural information detected do not top 50\%, meaning that-since $100 \%$ of the households were found to have at least one mobile phone- there are still at least 50\% of households not yet using their mobile phones in support of obtaining agricultural information and conducting their farming activities. 
Table 2: Respondents' use of mobile phones in support of farming activities $(n=58)$

\begin{tabular}{|c|c|c|c|}
\hline & Farming activity via mobile phone & $\begin{array}{c}\text { No. of } \\
\text { households } \\
\text { using mobile } \\
\text { phones for the } \\
\text { activity }\end{array}$ & $\begin{array}{l}\text { Percentage of } \\
\text { households using } \\
\text { mobile phones for } \\
\text { the activity }\end{array}$ \\
\hline 1 & general farming housekeeping & 29 & $50 \%$ \\
\hline 2 & enquire for inputs & 27 & $47 \%$ \\
\hline 3 & [obtain] weather information & 25 & $43 \%$ \\
\hline 4 & [obtain] market price for inputs & 23 & $40 \%$ \\
\hline 5 & pre-planting management & 21 & $36 \%$ \\
\hline 6 & [obtain] pest and disease control information & 19 & $33 \%$ \\
\hline 7 & animal husbandry & 18 & $31 \%$ \\
\hline 8 & post harvesting management & 15 & $26 \%$ \\
\hline 9 & [obtain] market price for produce & 14 & $24 \%$ \\
\hline
\end{tabular}

As seen in Table 2, the highest-percentage response for use of mobile phones in support of farming activities, at 50\%, was for use for "general farming housekeeping". The lowest percentage, at $24 \%$, was for use of a mobile phone for enquiring to "[obtain] market price for produce" - an interesting finding given the fact that, as we saw above, "absence of market information" was the second-most cited challenge faced in agricultural activities. (This apparent contrast between the farming households' strong felt need to get more market information and, at the same time, there weak adoption of mobile telephony as a means to acquire this information, is, at first glance, puzzling given that there are existing mobile agricultural information platforms in Zimbabwe, e.g., EcoFarmer, Mobi Agri, eMKambo and eHurudza. However, during the survey and the focus group discussion, it was found that not one of the respondents had heard of any of these platforms.)

\section{Researcher observations}

From the general observations I was able to make at the time of carrying out the research, those households that were using mobile phones in support of many of their farming activities were those that were comparatively well-resourced among the 58 surveyed households. These households tended to have homestead assets such as scotch carts (two-wheeled carts), granaries, and cattle. Meanwhile, the households not using mobile phones for agricultural purposes tended to be less-well-resourced. However, it was not within the ambit of this baseline research to probe potential correlations between livelihood success and mobile phone use for agricultural purposes. 


\section{Analysis, conclusions and recommendations}

This baseline study found that mobile phone use is prevalent among the smallholder farming households in Zimbabwe's Havana Extension village, with every household that participated in the research having at least one mobile phone of some sort. But at the same time, the study found that when respondents were prompted to consider how they might be using their mobile phones for farming activities, a full $50 \%$ (29) of the households did not select any of the nine options. Meanwhile, the two key agricultural challenges selected by more than $50 \%$ of respondent households were asymmetry of information (selected by $100 \%$ of households) and absence of market information (selected by $90 \%$ of households) - two challenges that could be addressed, at least to some extent, through acquisition of information via mobile telephony.

Thus, while much of the available literature (see Ilahiane \& Sherry, 2009; Masuka et al., 2016; Wyche \& Steinfield, 2016; Zanello, 2011) posits a relationship between farmers' mobile phone use and positive effects on the farmers' agricultural activities, the findings of this baseline study show that the relationship is by no means automatic, at least in respect of the farmer households in the particular Zimbabwean village studied.

It seems clear that many, if not all, of the smallholder farmers of Havana Extension could benefit, at least to some extent, from using their mobile phones to engage with one or more of the existing mobile agricultural platforms serving Zimbabwe, e.g., the aforementioned EcoFarmer, Mobi Agri, eMKambo and eHurudza. But, as mentioned above, none of the surveyed farmers said they knew of these platforms. Accordingly, there could be merit in the Zimbabwean Government taking a leading role in facilitating the development of an all-encompassing mobile application that could be used to disseminate agricultural information in respect of prices and availability of inputs (e.g., seeds, fertilisers, chemicals); and market information, as provided by different buyers, for sale of agricultural products.

Such a mobile application could facilitate negotiation between smallholder farmers and both input providers and agricultural product buyers. For instance, based on the information available through such an application, smallholder farmers could collectively negotiate with suppliers and send representatives to collect inputs on behalf of a group of farmers, thus cutting travel costs and allowing selection of wellpriced inputs. Similar collective actions could be undertaken for sale of the farmers' products.

Such an application could be supported by the Government of Zimbabwe through the Ministry of Agriculture. At the time of carrying out this research, the 
government, through the Ministry of Health and Child Welfare, was facilitating health information, through mobile phones, to all citizens. Therefore, it would seem that, with political will, an all-encompassing application in support of Zimbabwean smallholder agriculture could also come to fruition.

\section{References}

Adjognon, S. G., Liverpool-Tasie, L. S. O., \& Reardon, T. A. (2017). Agricultural input credit in Sub-Saharan Africa: Telling myth from facts. Food Policy, 67, 93-105. https://doi.org/10.1016/j.foodpol.2016.09.014

Aker, J. C., \& Mbiti, I. M. (2010). Mobile phones and economic development in Africa. The Journal of Economic Perspectives, 24(3), 207-232. https://doi.org/10.1257/jep.24.3.207

Annan, N. K. (2013). Leveraging mobile computing and communication technologies in education: Incorporation of mobile learning into tertiary education. Aalborg University. Retrieved from http://vbn.aau.dk/ws/files/198325048/Dissertation Final Copy for Publication.pdf

Arreymbi,J.,Agbor, E.A., \& Adnan, A. (2008). Critical analysis of why ICT uptake is slow in emerging economies - the case of Cameroon. In Proceedings of Advances in Computing and Technology, (ACEST), School of Computing and Technology 3rd Annual Conference, University of East London (pp. 165-178).

Asif, A. S., Uddin, M. N., Dev, D. S., \&Miah,M.A.M. (2017). Factors affecting mobile phone usage by the farmers in receiving information on vegetable cultivation in Bangladesh. Journal of Agricultural Informatics 8(2), 33-43. https://doi.org/10.17700/jai.2017.8.2.376

Bagazonzya, H., Safdar, Z., \& Sen, S. (2012). Broadening smallholders' access to financial services through ICT. Washington, DC: World Bank.

https://doi.org/10.1596/978-1-4648-1002-2 module7

Baumüller, H. (2015). Assessing the role of mobile phones in offering price information and market linkages: The case of M-Farm in Kenya. Electronic Journal of Information Systems in Developing Countries, 68(6), 1-16. https://doi.org/10.1002/j.1681-4835.2015.tb00492.x

Beuermann, D. W., McKelvey, C., \& Vakis, R. (2012). Mobile phones and economic development in rural Peru. Journal of Development Studies, 48(11), 1617-1628. https://doi.org/10.1080/00220388.2012.709615

Bonthu, P. (2014). India and China: A comparative analysis of mobile phones in agriculture. MA dissertation, University of Kansas, Lawrence, KS.

Brugger, F. (2011). Mobile applications in agriculture. Basel: Syngenta Foundation.

Calder, B. J. (1977). Focus groups and the nature of qualitative marketing research. Journal of Marketing Research, 14(3), 353-364. https://doi.org/10.2307/3150774

Chhachhar, A. R., Chen, C., \& Jin, J. (2016). Mobile phone impact on agriculture and price in-formation among farmers. Indian Journal of Science and Technology, 9(39), 1-11. https://doi.org/10.17485/ijst/2016/v9i39/98432

Churi, A. J., Mlozi, M. R. S., Tumbo, S. D., \& Casmir, R. (2012). Understanding farmers infor-mation communication strategies for managing climate risks in rural semi-arid areas, Tanzania. International Journal of Information and Communication Technology Research, 2(11), 838-845. 
Cooper, P. J. M., Dimes, J., Rao, K. P. C., Shapiro, B., Shiferaw, B., \& Twomlow, S. (2008). Coping better with current climatic variability in the rain-fed farming systems of subSaharan Africa: An essential first step in adapting to future climate change? Agriculture, Ecosystems and Environment, 126(1-2), 24-35. https://doi.org/10.1016/j.agee.2008.01.007

De Silva, H., \& Ratnadiwakara, D. (2008). Using ICT to reduce transaction costs in agriculture through better communication: A case study from Sri Lanka. Colombo: LIRNEasia. https://doi.org/10.2139/ssrn.1555458

Duncombe, R. (2012). Mobile phones for agricultural and rural development: A literature review and future research directions. Working Paper No. 50. Centre for Development Informatics, Institute for Development Policy and Management, University of Manchester.

Duncombe, R., \& Boateng, R. (2009). Mobile phones and financial services in developing countries: A review of concepts, methods, issues, evidence and future research directions. Third World Quarterly, 30(7),1237-1258. https://doi.org/10.1080/01436590903134882

Eliot \& Associates (2005). Guidelines for conducting a focus group. Retrieved from https:// datainnovationproject.org/wp-content/uploads/2017/04/4 How to Conduct a Focus Group-2-1.pdf

Etwire, P. M., Buah, S., Ouédraogo, M., Zougmoré, R., Partey, S. T., Martey, E., Dayamba, S. D., \& Bayala, J. (2017). An assessment of mobile phone-based dissemination of weather and market information in the Upper West Region of Ghana. Agriculture Eซ Food Security, 6(1), 1-9. https://doi.org/10.1186/s40066-016-0088-y

Food and Agriculture Organisation (FAO). (2011). Communication for development: Meeting today's agriculture and rural development challenges. Background Paper. Rome.

Foster, C., \& Heeks, R. (2013). Conceptualising inclusive innovation: Modifying systems of innovation frameworks to understand diffusion of new technology to low-income consumers. The European Journal of Development Research, 25(3), 333-355.

https://doi.org/10.1057/ejdr.2013.7

Furuholt, B., \& Matotay, E. (2011). The developmental contribution from mobile phones across the agricultural value chain in rural Africa. The Electronic Journal of Information Systems in Developing Countries, 48(1), 1-16.

https://doi.org/10.1002/j.1681-4835.2011.tb00343.x

Gabagambi, D. M. (2013). Barriers to trade for smallholder farmers in Tanzania. Dar es Salaam: PELUM Tanzania and ESAFF.

Hamad, M. A. A., Eltahir, M., Ali, A. E. M., Hamdan, A. M., \& Elsafi, A. A. H. (2018). Efficiency of using smart-mobile phones in accessing agricultural information by smallholder farmers in North Kordofan - Sudan.

https://doi.org/10.20944/preprints201809.0044.v1

Heeks, R. (2014a). Future priorities for development informatics research from the post-2015 development agenda. Working Paper No. 57. Centre for Development Informatics, Institute for Development Policy and Management, University of Manchester.

Heeks, R. (2014b). ICT4D 2016: New priorities for ICT4D policy, practice and WSIS in a post2015 world. Working Paper No. 59. Centre for Development Informatics, Institute for Development Policy and Management, University of Manchester. 
Idowu, S. O., Vertigans, S., \& Burlea Schiopoiu, A. (Eds.). (2017). Corporate social responsibility in times of crisis: Practices and cases from Europe, Africa and the world. New York: Springer. https://doi.org/10.1007/978-3-319-52839-7

Ilahiane, H., \& Sherry,J. (2009). Economic and social effects of mobile phone use in Morocco. Ethnology: An International Journal of Cultural and Social Anthropology, 48(2), 85-98.

Islam, M. S., \& Grönlund, Å. (2011). Bangladesh calling: Farmers' technology use practices as a driver for development. Information Technology for Development, 17(2), 95-111. https://doi.org/10.1080/02681102.2010.526093

Jagun, A., Heeks, R., \& Whalley, J. (2008). The impact of mobile telephony on developing country micro-enterprise: A Nigerian case study. Information Technologies and International Development, 4(4), 47-65. https://doi.org/10.1162/itid.2008.00026

Jayne, T. S., Mather, D., \& Mghenyi, E. (2006). Smallholder farming under increasingly difficult circumstances: Policy and public investment priorities for Africa. MSU International Development Working Paper No. 86. Department of Agricultural Economics, Michigan State University, East Lansing, MI.

Katengeza, S. P., Kiiza, B., \& Okello, J. J. (2011). The role of ICT-based market information services in spatial food market integration. International Journal of ICT Research and Development in Africa, 2(1), 1-14. https://doi.org/10.4018/jictrda.2011010101

Kavoi, J. M., Mwangi, J. G., \& Kamau, G. M. (2014). Challenges faced by small land holder farmer regarding decision making in innovative agricultural development: An empirical analysis from Kenya. International Journal of Agricultural Extension, 2(2), 101-108.

Khayyat, N.T., \& Heshmati, A. (2013). Determinants of mobile telecommunication adoption in Kurdistan. International Journal of Communication, 7, 2285-2311.

Kiilu, E. M. (2013). Delivery of service quality in the mobile telephony industry in Kenya. Master of Business Administration research paper, School of Business, University of Nairobi.

Kushchu, I., \& Kuscu, M. H. (2004). Mobile government. Retrieved from http://unpan1. un.org/intradoc/groups/public/documents/apcity/unpan040049.pdf

Leon, N., Schneider, H., \& Daviaud, E. (2012). Applying a framework for assessing the health system challenges to scaling up mHealth in South Africa. BMC Medical Informatics and Decision Making, 12(23), 1-12. https://doi.org/10.1186/1472-6947-12-123

Mago,S.(2012).Theimpactofinformationandcommunicationtechnologies(ICTs)onrurallivelihoods: The case of smallholderfarming. Master's thesis, Universityof FortHare, Alice, South Africa. http://hdl.handle.net/10353/d1007185

Mansingh, P., \& Erena, F. A. (2016). Impact of mobile phone technology on agriculture and rural development: An analysis. International Journal of Current Research, 8(5), 3131131317.

Marshall, S. J. (2018). Shaping the university of the future: Using technology to catalyse change in university learning and teaching. Singapore: Springer.

Martin, B. L., \& Abbott, E. (2011). Mobile phones and rural livelihoods: Diffusion, uses, and perceived impacts among farmers in rural Uganda. Information Technologies and International Development, 7(4), 17-34. 
Masaba, C. M. (2013). Impacts of investment and the principles for responsible agricultural investment (PRAI) on African agriculture - lessons of effective partnerships from Uganda. Presentation to 5th Tokyo International Conference on African Development (TICAD), Yokohama, 1-3 June.

Masuka, B., Matenda, T., Chipomho, J., Mapope, N., Mupeti, S., Tatsvarei, S., \& Ngezimana, W. (2016). Mobile phone use by small-scale farmers: A potential to transform production and marketing in Zimbabwe. South African Journal of Agricultural Extension (SAJAE), 44(2), 121-135. https://doi.org/10.17159/2413-3221/2016/v44n2a406

Mekuria, F. (2007). Using mobile technology and services for sustainable development in Africa. In J. Aisbett, G. Gibbon, A. J. Rodrigues, J. K. Migga, R. Nath, \& G. R. Renardel (Eds.), Strengthening the role of ICT in development, Volume IV (pp. 290-295). Kampala: Fountain Publishers.

Minges, M. (2016). Exploring the relationship between broadband and economic growth. Background Paper prepared for the World Development Report 2016: Digital Dividends.

Mittal, S. (2012). Modern ICT for agricultural development and risk management in smallholder agriculture in India. Socioeconomics Working Paper 3. New Delhi: CIMMYT (International Maize and Wheat Improvement Center).

Mittal, S., \& Mehar, M. (2012). How mobile phones contribute to growth of small farmers? Evidence from India. Quarterly Journal of International Agriculture, 51(3), 227-244.

Morawczynski, O. (2010). Examining the adoption, usage and outcomes of mobile money services: The case of M-PESA in Kenya. Master's thesis, Science and Technology Studies, University of Edinburgh.

Mugova, S., Mudenda, M., \& Sachs, P. R. (2017). Corporate social responsibility in challenging times in developing countries. In S. O. Idowu, S. Vertigans, \& A. Burlea Schiopoiu (Eds.), Corporate social responsibility in times of crisis: Practices and cases from Europe, Africa and the world (pp. 207-228). New York: Springer International. https://doi.org/10.1007/978-3-319-52839-7 11

Murray, U., Gebremedhin, Z., Brychkova, G., \& Spillane, C. (2016). Smallholder farmers and climate smart agriculture: Technology and labor-productivity constraints amongst women smallholders in Malawi. Gender, Technology and Development, 20(2), 117-148. https://doi.org/10.1177/0971852416640639

Musungwini, S. (2014). Harnessing mobile technology (MT) to enhance the sustainable livelihood of rural women in Zimbabwe. Case of mobile money transfer (MMT). International Journal of Computer Science and Business Informatics, 14(2), 46-57.

Musungwini, S. (2016). A model for harnessing the power of mobile phone technology to improve smallholder agriculture in Zimbabwe. In O. P. Zacarias, \& C. W. Larsson (Eds.), Proceedings of the 5th International Conference on M4D Mobile Communication Technology for Development: M4D 2016, General Tracks (pp. 237-252). Karlstad, Sweden: Karlstad University Studies.

Musungwini, S., \& Van Zyl, I. (2017). 'Mobile technology for development' experiences from Zimbabwe vending markets[:] A naturalistic enquiry. International Journal of Business and Management Studies, 6(1), 101-112. http://www.universitypublications. net/ijbms/0601/html/P6G85.xml 
Musungwini, S., Zhou Tinashe, G., Zhou, M., \& Ruvinga, C. (2014). Harnessing social media for business success. Case study of Zimbabwe. International Journal of Computer Science and Business Informatics (IJCSBI), 11(1), 80-89.

Mutami, C. (2015). Smallholder agriculture production in Zimbabwe: A survey. Consilience: The Journal of Sustainable Development, 14(2), 140-157.

Mutisya, C. (2016). New media and business: Adoption and use of mobile phone technology services in empowering women entrepreneurs in Machakos County. $\mathrm{PhD}$ dissertation, University of Nairobi.

Ndiwalana, A., Morawczynski, O., \& Popov, O. (2008). Mobile money use in Uganda: A preliminary study. GSMA Mobile for Development. Retrieved from https://www. gsma.com/mobilefordevelopment/wp-content/uploads/2012/06/m4dmobilemoney. pdf

Nguthi, F. (2007). Adoption of agricultural innovations by smallholder farmers in the context of HIVIAIDS: The case of tissue-cultured banana in Kenya. PhD thesis, Wageningen University, Wageningen, The Netherlands. Retrieved from http://edepot.wur.nl/121905

Nkomo, S. (2016). An assessment of Zimbabwe's Indigenisation and Economic Empowerment (ZIEE) Policy. Master's research essay, University of Botswana, Gaborone.

Ogbeide, O. A., \& Ele, I. (2015). Smallholder farmers and mobile phone technology in Sub-Sahara agriculture. Mayfair Journal of Information and Technology Management in Agricul-ture, 1(1), 1-19.

Ogunleye, O. S. (2010). Explosion of mobile and wireless technologies - An[d] opportunities for mobile government to speed up service deliveries: A South African perspective. In Proceedings of mLife 2010 Conferences, Brighton UK, 27-29 October.

Olsen, C. (2008, December 1). The mobile economy. Adweek. Retrieved from https://www. adweek.com/brand-marketing/mobile-economy-97609/

Organisation for Economic Co-operation and Development (OECD), \& International Telecommunication Union (ITU). (2011). M-government: Mobile technologies for responsive governments and connected societies.

https://doi.org/10.1787/9789264118706-en

Page, M., Molina, M., Jones, G., \& Makarov, D. (2013). The mobile economy 2013. London: GSMA and A.T. Kearney. Retrieved from http://www.atkearney.com/ documents/10192/760890/The Mobile Economy 2013.pdf

Palmer, N. (2012). Using ICT to enable agricultural innovation systems for smallholders. Summary of online forum discussion. Food and Agriculture Organisation (FAO), e-Agiculture, and World Bank. Retrieved from: http://www.fao.org/docrep/018/ ar130e/ar130e.pdf

Pienaar, L., \& Traub, L. N. (2015). Understanding the smallholder farmer in South Africa: Towards a sustainable livelihoods classification. Paper presented to $29^{\text {th }}$ International Conference of Agricultural Economists: Agriculture in an Interconnected World, Milan, 8-14 August. Retrieved from https://ideas.repec.org/p/ags/iaae15/212633.html

Potnis, D. D. (2014). Beyond access to information: Understanding the use of information by poor female mobile users in rural India. The Information Society, 31(1), 83-93. https://doi.org/10.1080/01972243.2014.976687 
Pshenichnaya, N., \& Palmer, T. (2013). Tigo baseline report executive summary. London: GSMA mAgri. Retrieved from http://www.gsma.com/magri

Qiang, C. Z, Kuek, S. C., Dymond, A., \& Esselaar, S. (2011). Mobile applications for agriculture and rural development. Washington, DC: World Bank ICT Sector Unit.

Qureshi, S., \& Najjar, L. (2017). Information and communications technology use and income growth: Evidence of the multiplier effect in very small island states. Information Technology for Development, 23(2), 212-234. https://doi.org/10.1080/02681102.2016.1173634

Rashid, A. T., \& Elder, L. (2009). Mobile phones and development: An analysis of IDRCsupported projects. The Electronic Journal of Information Systems in Developing Countries, 36(1), 1-16. https://doi.org/10.1002/j.1681-4835.2009.tb00249.x

Samukange, T. (2014, February 21). Zimbabwe records 75 company closures, over 9000 job losses. Nerwsday. Retrieved from https://www.newsday.co.zw/2014/02/zimbabwerecords-75-company-closures-9-000-job-losses/

Shaffril, H. A. M., Omar, S. Z., D’Silva, J. L., \& Bolong, J. (2015). Mapping the patterns of mobile phone usage among fishermen in Malaysia. Information Technology for Development, 21(4), 543-554. https://doi.org/10.1080/02681102.2014.899962

Tadesse, G., \& Bahiigwa, G. (2015). Mobile phones and farmers' marketing decisions in Ethiopia. World Development, 68, 296-307. https://doi.org/10.1016/j.worlddev.2014.12.010

Trading Economics. (n.d.). Zimbabwe population. Retrieved from https://tradingeconomics. com/zimbabwe/population

United Nations (UN). (n.d.). Sustainable Development Goals. Retrieved from https://www. un.org/sustainabledevelopment/sustainable-development-goals/

Van Zyl, I. (2013). Technology encounters and the symbolic narrative: Localising the 'technology for development' experience in South African education settings. $\mathrm{PhD}$ dissertation, Faculty of Communication Sciences, University of Lugano, Switzerland. https://doi.org/10.23962/10539/21654

Von Loeper, W., Musango, J., Brent, A., \& Drimie, S. (2016). Analysing challenges facing smallholder farmers and conservation agriculture in South Africa: A system dynamics approach. South African Journal of Economic and Management Sciences, 19(5), 747-773. https://doi.org/10.4102/sajems.v19i5.1588

Vusani, M. R. (2015). The economic downfall of Zimbabwe from 1980 to 2008. Faculty of Education, Africa University, Mutare, Zimbabwe.

Walsh, C., \& Power, T. (2011). Rethinking development and the use of mobile technologies: Lessons from Bangladesh. In Global Learn Asia-Pacific 2011, 28 April - 1 May. Retrieved from http://oro.open.ac.uk/28482

Wamuyu, P. K. (2014). The role of contextual factors in the uptake and continuance of mobile money usage in Kenya. The Electronic Journal of Information Systems in Developing Countries, 64(4), 1-19. https://doi.org/10.1002/j.1681-4835.2014.tb00457.x

Waverman, L., Merschi, M., Fuss, M., \& Gough, N. (2005). Africa: The impact of mobile phones. The Vodafone Policy Paper Series No. 2. Retrieved from https://www.vodafone.com/ content/dam/vodafone/about/public policy/policy papers/public policy series 2.pdf 
World Bank. (2011). ICT in agriculture: Connecting smallholders to knowledge, networks, and institutions. https://doi.org/10.1596/12613

World Bank (2012). Information and communications for development 2012: Maximising mobile. https://doi.org/10.1596/978-0-8213-8991-1

Wulystan,P. M.,\&Andrew,C. M.(2013).Using information and communication technologies for enhancing the accessibility of agricultural information for improved agricultural production in Tanzania. Electronic Journal of Information Systems in Developing Countries, 56(1), 1-14. https://doi.org/10.1002/j.1681-4835.2013.tb00395.x

Wyche, S., \& Steinfield, C. (2016). Why don't farmers use cell phones to access market prices? Technology affordances and barriers to market information services adoption in rural Kenya. Information Technology for Development, 22(2), 320-333. https://doi.org/10.1080/02681102.2015.1048184

Zanello, G. (2011). Does the use of mobile phones reduce transactions costs and enhance participation in agricultural markets? Household evidence from northern Ghana. Retrieved from https://editorialexpress.com/cgi-bin/conference/download.cgi?db name=res phd 2012\&paper id=59

Zimbabwe National Statistics Agency (ZIMSTAT). (2012). Census 2012: National report. Harare. Retrieved from http://www.zimstat.co.zw/sites/default/files/img/publications/ Population/National Report.pdf

Zyl, O. V., Alexander, T., Graaf, L. D., \& Mukherjee, K. (2014). ICTs for agriculture in Africa. Washington, DC: World Bank.

\section{Appendix: Survey questionnaire}

This study is important because smallholder farmers have become critical in the economic welfare of Zimbabwe. Over the past two decades the Zimbabwe economy experienced a continued downfall which resulted in the collapse of the commercial farming and the agribusiness formal industry. As a result farmers are faced with challenges when it comes to selling their products. Therefore understanding the smallholder farmers' operations and how they are using mobile technologies in their business has become critical to the ICT4D [ICT for development] discourse. This study will provide greater nuances to the people into the understanding of the implications of mobile communication technologies to assist in the achievement of development initiatives.

Your responses will only be used for the purposes of this research. To ensure your anonymity, you will not be asked about your name $[\ldots]$.

1) What are the agricultural practices you are involved in? Please tick all that apply to you.

$\begin{aligned} \text { I. } & \text { Cereals } \\ \text { II. } & \text { Cash crops } \\ \text { III. } & \text { Market gardening } \\ \text { IV. } & \text { Livestock keeping } \\ \text { V. } & \text { Poultry }\end{aligned}$


2) What are the challenges you face in the agricultural activities? Please tick all that apply to you.

I. Asymmetry of information

II. High production costs

III. Absence of market information

IV. Lack of capital

V. Challenge of finding agriculture inputs

VI. $\quad$ Crop and animal diseases

3) What are the sources of agricultural information for you? Please tick all that apply to you.
I. Radio
II. Television
III. Agritex
IV. Word of mouth
V. Mobile phones

4) a) Does anyone in the household own a mobile phone? Tick where appropriate.
I. Yes
II. No

b) Does anyone in the household own a smartphone? Tick where appropriate.
I. Yes
II. No

c) What do you use the mobile phone for? Please tick all that apply to you.
I. Listening to radio
II. Voice calling
III. SMS
IV. Photography
$V$. Mobile money services
VI. Facebook and other internet services
VII. WhatsApp

d) Which farming activities do you use your mobile phone for? Please tick all that apply to you.

$\begin{array}{ll}\text { I. } & \text { Pre-planting management } \\ \text { II. } & \text { Enquire for inputs } \\ \text { III. } & \text { Market price for inputs } \\ I V . & \text { Market price for produce } \\ V . & \text { Pest and disease control information } \\ \text { VI. } & \text { General farming housekeeping } \\ \text { VII. } & \text { Weather information } \\ \text { VIII. } & \text { Post harvesting management } \\ \text { IX. } & \text { Animal husbandry }\end{array}$

